\title{
Study on the Path for the Construction of China's Rural Credit System
}

\author{
Gujun Yan \\ Institute for the Study of Finance, \\ Zhejiang University, \\ Hangzhou, P. R. China 310027 \\ Email: zjujt@163.com
}

\begin{abstract}
Accelerating the construction of credit system in the countryside is an effective way to meet the fund demands of the "agriculture, countryside and farmers", because it helps to prevent credit risks, improve farmers' access to credit, and reduce the cost of financial transactions. In the long run, to speed up the rural credit system construction, the important thing is to attach importance to the legal system construction for rural credit system and quicken the pace of credit reporting industry legislation. Also important is to promote the establishment of a powerful, easy-to-use rural credit information sharing platform by the aid of the leading role of the government.
\end{abstract}

Keywords-Farmers; Credit rewards and punishment mechanism; Credit information; Rural credit system

\section{The Basic Characteristics OF CURRENT RuRAL CREDIT}

Because of the particularity of the rural economy and society, rural credit exhibits certain characteristics that are different from cities. So, in the process of building rural credit system, we need to design suitable frameworks and mechanisms that are combined with the reality of rural credit features. Overall, the unique feature of rural credit is mainly manifested in following aspects:

Firstly, family is often as a credit body. In large scale, farm household is the basic production and business operation entity, and also the core unit of rural consumption. This determines the main body of rural credit is farm households. Then, personal credit registry system based on individuals is difficult to fully adapt to rural production and living ways, and emphasis should be put on families as a whole when constructing the credit reporting system. As for the credit records, in addition to personal credit information of the head of the farm household, we still need to collect information on family members, household major asset, household debt, family production, and other family-based related information. Meanwhile, with respect to urban families, rural families often have more members and more complex relations, which also make the construction of rural credit system more complicated.

Secondly, there exists the layer feature in credit relationships. Credit relations in the countryside are mainly family-centered, then from family to clan, from clan to village, from the village to the town, and layer-by-layer outward, showing a circle structure characteristic. This layer structure is led and restricted by the blood and geopolitical relations, which means that closer to the home, smaller is the circle and more closely is the trust relationship. Inside such limited circles, usually there exists a "hidden credit mechanism" [1], that is to say, the "credit history" of someone in the circle is accumulated by the "word of mouth", which can be shared easily within the circle. However, with the gradual deepening of urbanization and continuous expanding of market trading range, the original limited circle of credit based on interpersonal trust will increasingly not adapted to the development trend of transformation of the rural economy in the new period. To this end, we need to gradually build up the corresponding formal credit system arrangements in rural markets.

Thirdly, the credit structure is diversified. In the cities' credit structure, formal bank credit accounts for the majority share. However, in rural areas, in addition to bank credit, various forms of informal folk credit are widespread, and occupy an important position in the credit markets. This makes the rural credit structure and financing forms more complex than in the city.

Fourthly, the credit risk control is affected more by external factors. Agriculture may suffer from various kinds of disasters with high frequency and great losses, and rural production is often influenced by environment and other nonhuman factors, thus makes the farmers' income instable. While off-farm income, such as migrant workers income, is becoming an important part of farmers' income, it lacks guarantee of stability and continuity. This situation will inevitably affect the performance ability and credit status of farmers. In many cases, farmers credit cannot be entirely controlled by farmers themselves, showing obvious external characteristics [2].

\section{Existing Problems IN THE Construction OF RURAL CREDIT SYSTEM}

Generally speaking, rural credit system construction in China is still at an early stage and faces many urgent problems. 
A. The construction of rural credit system lacks effective protection of laws and regulations

So far, China has not yet established complete legal framework on social credit system, and especially lacks specific rules and regulations for the rural credit system construction, resulting in the construction of rural credit system in status of lawlessness and lack of legal protection. Specifically, there is no standardized guideline for the subject of collection of farmers' credit information, the scope of information query and approach of credit information sharing; there is no legal basis for how to protect the personal privacy and commercial secrets involved in credit information; there is no rules on incentives to promise keepers and punishment to the dishonest. Obviously, the lack of legal support and protection system has become a prominent problem restricting the construction of rural credit system.

\section{B. Credit incentive mechanism is not perfect}

Credit rewards and punishment mechanism is the driving force for credit system to continue to function. In recent years, some regions have been taking measures such as lower interest rates, simplified loan procedures, and relaxed lines against "credit farmer, credit village and credit town", and giving "blacklisted", no loans and other sanctions against bad faith farmers, villages and towns. From the point of actual effect, those measures have played a certain incentive effect. However, the existing credit incentive and restraint mechanisms is still confined to be used in the process of financial institutions' lending to farmers, and has not been reflected in the wide range of areas. Some local governments have introduced skewed policies in agricultural infrastructure construction and selection of new agricultural projects to "credit town, credit village and credit farmer", but such policies often become a mere formality due to lack of detailed implementing rules. Overall, on incentive and disciplinary forces is concerned, the current rural credit incentive and constraint mechanism is not strong, and is yet to be further improved.

\section{Rural credit information is difficult to collect and update}

Credit information of agriculture-related economic entities is distributed in a number of departments such as the tax authority, court, land department and financial institutions. For the comprehensive integration of credit information, it is necessary to build up effective mechanism of cooperation between all related departments. But currently, the credit reporting system is mainly constructed by financial institutions themselves, and is difficult to aggregate information held by the relevant departments other than financial institutions, making information collection incomplete. Moreover, farmers and rural small businesses are often unable to provide detailed and accurate financial statement information, and collection of their information can only be achieved by means of direct investigation. Because farmers and rural small businesses are large-numbered and geographically dispersed, the information gathering may be difficult and time-consuming. In addition, with the development of rural urbanization and more and more rural migrant population, the increased mobility of rural population also brings inconvenience to farmers' information collection and tracking, and even make some farmers drifted away from the credit system.

\section{The construction of farmers' credit information database lack overall plans and credit information is difficult to be shared}

At present, China has preliminarily established personal and business credit information database led by the people's Bank of China, but the scope for information collection is narrow, especially information about the farmer is not complete. Meanwhile, in many areas, rural credit cooperatives, postal savings banks, the agricultural bank of China and other agriculture-related financial institutions, have also carried out establishment of credit archives work, resulting in the phenomenon of the same farmer having personal records at different banks and the repeated construction of farmers' credit information database. On the one hand, this leads to enormous waste of human and material resources in credit information system construction; on the other hand farmers' credit file established by each agriculture-related financial institution is only used for its own credit business management and not available to the outside, making it difficult to achieve resource sharing of farmers credit information among various financial institutions.

\section{Ways to Promote RuRal Credit System CONSTRUCTION}

To effectively promote the construction of rural credit system in China, it will be necessary to make innovations in credit reporting mechanism, standardize and improve credit evaluation mechanism, and perfect credit rewards and punishment mechanism.

A. Giving full play to the leading role of local governments in the construction of rural credit system through innovation of working mechanism

Credit information collection and evaluation of farmers has the characteristic of dispersion, and the cost of credit rating conducted by intermediaries is high. Also, the pattern that agriculture-related financial institutions undertake the construction of peasant household credit information system may encounter the bottleneck of information acquisition and sharing, because agriculture-related financial institutions can only collect the information of customers who do business with them, and they lack of willingness to share household credit information with other financial institutions [3; 4]. As a result, the local government-led promotion of rural credit system construction has become a rational choice.

Firstly, the local government should strengthen organization and coordination to straighten out the working mechanism of the rural credit system construction. Rural credit system construction involves many departments, which requires local governments to establish a unified department in charge of the construction so as to rationalize the relationship between various sectors. Obviously, the forming of a longterm working mechanism of multi-party cooperation and coordination can help to facilitate the mobilization of all forces to jointly promote the rural credit system construction. 
Secondly, local governments should provide necessary funding. This means that local governments need to give financial supports to the development and maintenance of rural credit information system platform, credit information collection and update, and publicity and training. Local governments also need to establish a special fund used for interest subsidies to trustworthy farmers to stimulate the enthusiasm of farmers to participate in the construction of rural credit system.

Thirdly, local governments should insert credit system construction into the assessment mechanism for rural grassroots organizations. That is to say, local governments should include the construction situation of "credit farmer and credit village (town)" within their jurisdiction in the annual assessment content, in order to encourage township governments, village committees and other rural grass-roots organizations to concern about the credit situation of local farmers and enterprises, and play their positive roles in the construction of credit system in the countryside.

\section{B. Improving the legal safeguard mechanism for rural credit system construction}

Healthy and orderly construction of rural credit system is inseparable from complete laws and regulations as a safeguard. China should step up the formulation of laws and regulations on the construction of rural credit system so as to stipulate the rights and obligations of the ratings clients and information sources providers, and gradually form a good legal environment under which the rural credit information collection, query, use, supervision and rating are all on the legal basis.

First of all is to pay close attention to formulate basic laws needed for the construction of credit system, such as the "Social Credit Law" and "Credit Information Disclosure Act", to provide a fundamental legal basis for the credit information collection, disclosure, use and protection of trade secrets and personal privacy.

The second is, under the basic legal framework, to further develop special laws and regulations on rural credit system construction based on the rural reality, such as the "Farmers Credit Regulations", for the purpose of clearing the contents of the rural credit system, credit reporting procedures, dispute handling and legal responsibility, and regulating the behaviors of rural credit information providers and users. Also necessary is to revise and improve the terms on credit content involved in the "Criminal Law", "Bankruptcy Law", "Property Law", "Contract Law", "Guarantee Law" and "Commercial Bank Law", to strengthen the protection of legitimate rights and interests of creditors, regulate the behavior of credit market participants and form a set of matched system of laws and regulations.

\section{Improving credit incentive and disciplinary mechanism}

Building a disciplinary mechanism of "trustworthy benefits, dishonesty loses", which means to motivate promise keepers and give penalties on bad credit, can provide effective support for the sustainable development of the rural credit system construction. To this end, in addition to further guiding agriculture-related financial institutions to really take preferential measures to credit farmers in lending right, interest rates and loan application process, and to crack down on malicious debt evasion behavior, the priority needs to be put on expanding the scope of application of credit history and credit rating results. Specifically, the application scope should be expanded from financial services to a wide range of areas such as agricultural subsidy, social security, government procurement and public servants employment, and gradually increase the depth of the using of credit information in above fields. Credit records being more fully utilized in various fields will help improve the internal driving force of rural economic subjects to be honest and trustworthy. At the same time, we should pay attention to strengthen the constraint functions of the reputation mechanism. Reputation can provide a kind of implicit incentive for participants who care about long-term interests. Because of the limited geographical scope, circle structure and other characteristics of rural credit, reputation mechanism is more able to play its role effectively in the construction of credit system in rural areas [5]. Correspondingly, it will be necessary to establish reputation information disclosure and dissemination mechanisms by way of regularly disclosing the results of previous credit evaluation in the relevant areas and online notification of default credit customers.

\section{Standardizing the rural credit evaluation mechanism}

Credit evaluation result is an important reference to financial institutions' credit approval and risk control. In recent years, China has carried out the assessment of "credit farmer, credit village and credit town" throughout the country. However, due to mixed evaluation index and assessment criteria among agriculture-related financial institutions, credit evaluation results may show great differences, which may affect their social credibility. At the same time, the same object may be assessed by different financial institutions, thus will unavoidably result in a waste of human and material resources. Also, each agriculture-related financial institution often do not recognize other institution's assessment results, which makes farmers cannot effectively release their credit status signal through an assessment. To change this situation, on the basis of the implementation of peasant household credit information sharing, first of all participants of rural credit system construction should formulate a set of scientific and unified credit scoring standards. Secondly, the assessment results based on unified scoring criteria should be fitted into the information collection scope of peasant household credit information database, thus to achieve mutual recognition of evaluation results among agriculture-related financial institutions and to facilitate farmers' loan applications. Furthermore, the linked mechanism of credit evaluation results to line of credit, loan interest rate and credit collateral requirements should be improved too, in order to give full play to the positive incentive effect of credit reviews.

\section{E. Establishing a unified rural credit information sharing platform to make innovations in credit reporting mechanism}

Designing credit reporting system suited to the characteristics of the rural economy and credit is a basic step 
in the construction of rural credit system. In view of the regional characteristics of the rural economy and taking into account the cost of system construction, it should take the region with the same economic characteristics as a unit to build rural credit information system. Overall, taking municipal area as a unit is more appropriate currently [6]. After the level of rural financial transaction activities has been improved, we can implement networking within a larger regional context. A full-featured, open and compatible farmer's credit information sharing service platform which is formed on the basis of integration and optimization of information gathering indicators will help agriculture-related financial institutions save pre-loan investigation cost and improve auditing work efficiency of agriculture-related loans.

In order to establish a unified rural credit information sharing platform, it is necessary to accelerate information communication within different sectors to break information blockade and input relevant information of rural economic entities into the credit information management system. Also necessary is to take unified management and formulate credit data opening standards and rights to realize information sharing across financial institutions engaged in agriculturerelated financial services. The completion of rural credit information sharing platform can not only satisfy the query needs of farmers' credit information, but also avoid the problem of repeated construction of local credit system. Predictably, the formation of rural credit information sharing mechanism based on joint acquisition, safeguard and using among financial institutions and agriculture-related departments, is bound to promote a virtuous cycle of rural credit system construction.

\section{CONCLUSION}

Although the rural credit system in China has made some achievements in recent years, there still exist many problems, such as unsound credit rewards and punishment mechanism, imperfect credit information sharing mechanism, and so on. To further perfect China's rural credit system, it is necessary to establish a unified rural credit information sharing platform, standardize evaluation system for the rural credit, and improve legal protection mechanisms.

\section{REFERENCES}

[1] Wang Guitang, "The 'Hidden Credit' in rural credit activities and its efficiency”, Financial Theory \& Practice, 8:pp.25-27,2010.( In Chinese)

[2] Wu Jingmei, et al, "Research on the three dimensional credit evaluation model based on the credit characteristics of farmer households", Finance \&Trade Economics, 9: pp.22-29,2010. (In Chinese)

[3] Ye Xiekang, et al, "Rural cred it system construction and the problem of small loan for rural household”, Credit Reference, 3: pp.64-68,2012. ( In Chinese)

[4] Guo Sihua, "Study on the construction of rural credit system in China", Jiangxi Social Sciences, 8: pp.216-219, 2014. (In Chinese)

[5] Xiao Longcang, "Research on rural credit information system model in dual structure”, Journal of Financial Development Research, 2:pp.3-7, 2011. ( In Chinese)

[6] Zeng Zhiming, Yang Cailing, “On improving China’s rural credit system under the ecological perspective”, Journal of Hunan University of Commerce, 2: pp.97-101, 2013. ( In Chinese) 